\title{
PALAEODISTRIBUTION OF PYGMY-POSSUMS IN TASMANIA
}

\author{
by Jamie M. Harris and Jillian M. Garvey \\ (with one text-figure and one table)
}

\begin{abstract}
Harris, J.M. and Garvey, J.M. 2006 (30.xi): Palaeodistribution of pygmy-possums in Tasmania. Papers and Proceedings of the Royal Society of Tasmania 140: 1-10. https://doi.org/10.26749/rstpp.140.1 ISSN 0080-4703. School of Environmental Science and Management, Southern Cross University, New South Wales 2480, Australia (JMH*); Archaeology Program, School of Historical and European Studies, LaTrobe University, Victoria 3086, Australia (JG). *Author for correspondence.
\end{abstract}

This work is a contribution towards documenting the fossil distribution of the pygmy possums Cercartetus lepidus and C. nanus (Marsupialia: Burramyidae) in Tasmania. We provide locality data and bibliographic sources for 15 Quaternary fossil sites important for these species (i.e., Beeton Rockshelter on Badger Island, Cave Bay Cave on Hunter Island, Bone Cave, Derwent River Shelter 7, Kutikina Cave, Mackintosh Cave, Main Drain, March Fly Pot, Newdegate Cave, Nunamira, Ouse River Shelter 7, Peramerpar Meethaner, Pseudocheirus Cave, Warhol, and Warreen Caves on mainland Tasmania). Dates available for these sites span the period $3960 \pm 60$ to $34,790 \pm 510$ years ago. We also draw attention to a Late Oligocene fossil locality at Geilston Bay which produced an undescribed Cercartetus-like species. The recorded palaeodistribution of pygmy-possums in Tasmania is widespread, with sites on two offshore islands, and also in the southern, south western, and western areas of mainland Tasmania.

Key Words: Cercartetus, nanus, lepidus, Tasmania, distribution, fossil, Burramyidae.

\section{INTRODUCTION}

The eastern pygmy-possum Cercartetusnanus and little pygmypossum $C$. lepidus are diminutive burramyid marsupials that occur in Tasmania (15-43 g and 6-9 g respectively; Strahan 1995). Modern Tasmanian records for C. lepidus and C. nanus indicate that both species are widely distributed (Rounsevell $e t$ al. 1991, Munks et al. 2004). However, the recorded modern Tasmanian range of $C$. lepidus is more extensive than that of C. nanus (see range maps in Munks et al. 2004). Differences in the distribution of these two species reflect both their biogeographical history and subtle differences in their ecological requirements. Most records for $C$. nanus in Tasmania are from wet forests/rainforests (Green 1973, Watts 1987), whilst those for $C$. lepidus are from more xeric communities including dry sclerophyll forests andheathlands (Green 1979, Wall 1985). However, in some areas of Tasmania the range and habitats of these species are reported to overlap.

Outside Tasmania, C. lepidus is found on Kangaroo Island, South Australia (SA) (Aitken 1967, 1974), southeast mainland SA (Aitken 1977) and northwest Victoria (Ward 1992, Menkhorst 1995). Cercartetus nanus is found as far north as southeast Queensland (Harris et al. in press), through parts of mainly coastal New South Wales (NSW) (Bowen \& Goldingay 2000) and Victoria (Harris \& Goldingay 2005a), and west to the southeast of SA (Carthew 2004, van Weenen \& Harris 2006). On the mainland, the status of $C$. lepidus and $C$. nanus varies throughout their respective ranges from "Common" to "Vulnerable" (see Tulloch 2004). In Tasmania, the current status of both burramyids is recognised as "not threatened", but this is based on incomplete information and is in need of review (Duncan \& Taylor 2001, Munks et al. 2004).

A long-term perspective on the status and distribution of pygmy-possums can be gained by reference to information derived from their fossil occurrence in cave deposits. They are incorporated into the fossil record because several carnivorous marsupials and owl species prey on pygmypossums (and other small mammals) and deposit bones in caves as scats or regurgitated pellets; and also because pygmy-possums are susceptible to some pitfall-style caves (see Harris \& Goldingay 2005b). Caves provide excellent preservation sites for small mammal remains, and excavation and analysis at numerous cave sites in southern Australia have provided valuable information on past distribution patterns of mammalian species (e.g., Wakefield 1972, Archer 1974, Baynes 1987, Archer et al. 1991, Baird 1991, Baynes \& Johnson 1996).

In the case of the mountain pygmy-possum Burramys parvus, an assessment of its fossil distribution has shown a dramatic reduction in geographic range during the Late Pleistocene (Broome \& Mansergh 1989, Brammall 1993, Mansergh \& Broome 1994). A reduced distribution for $C$. lepidus is also apparent as fossil bones referable to this species have been discovered in areas where it is now extinct, i.e., in eastern NSW (Ride 1960) and eastern Victoria (Wakefield 1960). A preliminary investigation of the fossil occurrence of C. nanus in Victoria (Harris \& Goldingay 2005b) suggested that this species has not undergone a broad contraction of geographic range like $B$. parvus or $C$. lepidus. Examination of the distribution of fossil sites in South Australia however, indicates a recent range contraction (Harris in press). At present, there is very little published information on pygmypossum fossil remains from Tasmania, which limits current understanding of biogeographic patterns in the distribution of pygmy-possums through time across Australia. Hence, the aims of this contribution are: (i) to document available information on the fossil localities for pygmy-possums in Tasmania; (ii) plot the distribution of pygmy-possum fossil sites; and (iii) identify modes of accumulation involved at the various sites.

\section{METHODS}

The Southern Forests Archaeological Project (SFAP) CD (McWilliams et al. 1999), and several unpublished theses were examined with reference to pygmy-possum material 
recovered from Tasmanian archaeological cave sites. Records of Tasmanian fossil burramyids were also searched for in several journals including Australian Archaeology, Papers and Proceedings of the Royal Society of Tasmania, Tasmanian Cave and Karst Research Group Journal, and The Tasmanian Naturalist (Harris 2005). Several other published sources were also reviewed (see papers cited in Harris \& Goldingay 2005b). Additionally, enquiries were made with the palaeontology divisions of the Australian Museum (AM), Sydney; Museum Victoria (MV), Melbourne; Queen Victoria Museum and Art Gallery (QVMAG), Launceston; and Tasmanian Museum and Art Gallery (TMAG), Hobart. Geographic information for identified fossil sites was obtained from the relevant literature, the Geoscience Australia online place-name search (http://www. ga.gov.au/map/names/), or directly from topographic maps. We also sought information from the Tasmanian Aboriginal Site Index (TASI), administered by the Department of Tourism, Parks, Heritage and the Arts (DTPHA) for the Tasmanian Aboriginal Land and Sea Council (TALSC), the Aboriginal Heritage Office, DTPHA, academic staff in the School of Zoology, University of Tasmania, and from members of the Southern Tasmanian Caverneers Inc.

A multitude of taphonomic (preservation) biases can affect the abundance of pygmy-possums (and other small mammals) in cave sites. These include dietary selectivity, habitat preferences and physiological requirements of predatory accumulators, disparity in the ways that prey is eaten and digested, differential disappearance rates of prey remains, and temporal variability of predator and prey populations (see Garvey 1999, Harris \& Goldingay 2005b). Other factors include dispersal, scattering, or disintegration of bone due to gravity, stream wash, or the action of scavengers, including cave-trapped animals. Due to these and other biases operating inconsistently at the sites, we have not attempted to interpret stratigraphic data on the abundance of pygmy-possums, and have limited our investigation to reviewing whether Cercartetus material was reported as present/absent from the sites. This paper provides the first published list of known localities for fossil burramyids in Tasmania.

\section{RESULTS}

Material referable to Cercartetus has been reported from 15 Late Pleistocene and/or Holocene fossil sites in Tasmania (table 1). These include Cave Bay Cave on Hunter Island (Bowdler 1974a, 1982, 1984) and Beeton Rockshelter on Badger Island (Sim 1998), both to the north of mainland Tasmania (fig. 1). Pygmy-possum fossil and sub-fossil sites are also known from caves in the southern, southwestern and western areas of mainland Tasmania. The southern sites include Pseudocheirus Cave and March Fly Pot, which are two vertical caves in the Ida Bay karst, south of Lune River (Clarke 1988a, Muirhead 1990); Nunamira (formerly Bluff Cave) and Warhol (a vertical cave), both in the Florentine Valley section of the Junee-Florentine karst (Eberhard 1988, Cosgrove et al. 1990, Cosgrove 1991, 1996a, Cockbill 1999, McWilliams etal. 1999); and Newdegate Cave (H-1; formerly HX-7) in the Hastings karst, north of the Lune River (Clarke 1999, 2000). Southwestern sites are Bone Cave in the Weld River Valley (Northwood 1990, Allen 1996, McWilliams etal. 1999); Warreen (formerly known as M86/2) in the Maxwell River Valley (Allen etal. 1989, Cockbill 1999, McWilliams et al. 1999), and Kutikina Cave (formerly Fraser Cave) on the
Franklin River (Smith \& Sharp 1993, Geering 1983, Jones et al. 1983, Kiernan et al. 1983; Jones 1990; Garvey 2006) (fig. 1). Sites in western Tasmania are Main Drain, a limestone cave at Bubs Hill, east of Queenstown (Clarke 1988b, 1989) and Mackintosh Cave on a tributary of the Pieman River (Stern \& Marshall 1993, McWilliams etal. 1999). Sites outside these areas are the Ouse River Shelter 7 rockshelter (ORS 7) in the Shannon River Valley (Cosgrove et al. 1990, Cosgrove 1991, 1996b, McWilliams et al. 1999), Permerpar Meethaner rockshelter in the upper Forth Valley (Cosgrove 1995, 1999), and Derwent River Shelter 7 rockshelter (DRS 7) on the Derwent River (Garvey 1999).

Of particular significance for the antiquity of pygmypossums is a Late Oligocene fossil locality at Geilston Bay (Tedford et al. 1975, Rich et al. 1982, Tedford \& Kemp 1998). A single right lower incisor collected from this site was the only identified remains of a species assignable to the family Burramyidae. The incisor was described by Tedford \& Kemp (1998:16) as "most similar to those of Cercartetus and Burramys, especially the former, although it is about twice the size of any living species of that genus". Further work may provide evidence to determine whether it is indeed a burramyid.

The literature pettaining to some of these sites provides information on counts of Minimum Number of Individuals (MNI) from different stratigraphic units. For example, for Cave Bay Cave, Bowdler (1984) reported a total of 52 C. nanus, with these being from the "Upper Midden" (MNI=25), "Sterile Layer" (MNI=10), "Lower Midden" (MNI=2), "Upper Pleistocene < 19,000 BP" (MNI=2) and "Lower Pleistocene $\geq 19,000$ BP" (MNI=13). For $C$. lepidus, Bowdler (1984) reported that three specimens were collected, one from the "Lower Midden" and two from the "Lower Pleistocene $\geq 19,000$ BP" unit. Clarke (1988b, 1989) recorded a single fragmented burramyid specimen from Main Drain, tentatively assigned to $C$. nanus. In the case of the two vertical caves at Ida Bay, there were two C. nanus and one C. lepidus retrieved from March Fly Pot, and for Pseudocheirus Cave there were 19 C. nanus and three C. lepidus retrieved (Muirhead 1990). For Warhol, Eberhard (1988) reported a single Cercartetus specimen that was cautiously assigned to $C$. lepidus.

In his study of the owl pellet remains from Newdegate Cave, Clarke (2000) recorded two specimens of both $C$. nanus (mandible and humerus) and C. lepidus (mandibles). For DRS 7, Garvey (1999) identified remains of C. nanus (MNI=26) and also some some fragmentary remains attributed to Cercartetus sp. $(\mathrm{MNI}=8)$, which may have been either C. nanus or C. lepidus. For Permerpar Meethaner, counts of $C$. nanus specimens in the excavated material have not been published, but Cosgrove (1995:94) stated that this species was "identified in all spits". For Nunamira and ORS 7, Cosgrove (1991) presented preliminary stratigraphic data for Cercartetus spp., although these data have now been updated by the SFAP database (McWilliams et al. 1999). Similarly, preliminary counts of C. lepidus and $C$. nanus in several unpublished theses (i.e., Warreen-Cockbill 1999; Bone Cave-Northwood 1990) are also superseded by McWilliams et al. (1999).

The SFAP database currently contains records of Cercartetus material excavated from five caves in Tasmania (Bone Cave, Mackintosh, Nunamira, ORS 7 and Warreen). For Bone Cave, two C. nanus left mandibles were recorded from Square B spit $2(\mathrm{ID}=29753)$ and Square B spit 3 $(\mathrm{ID}=29841)$. For Mackintosh, the database indicates that 11 
TABLE 1

Location and reported ages of fossil Cercartetus remains in Tasmania.

\begin{tabular}{|c|c|c|c|c|c|c|c|c|c|c|c|}
\hline Site Name & $\mathrm{Cl}$ & $\mathrm{Cn}$ & Cspp. & KI code & Site code & TASI code & Origin & Age (yr BP) & Latitude & Longitude & Sources \\
\hline Cave Bay Cave & + & + & - & $\mathrm{H} 1-\mathrm{X} 1$ & - & 0031 & MS, OP & $22,750 \pm 420$ to $18,550 \pm 600$ & $40^{\circ} 34^{\prime} \mathrm{S}$ & $144^{\circ} 45^{\prime} \mathrm{E}$ & Bowdler 1974a, 1982, 1984 \\
\hline Beeton Rockshelter & + & + & - & - & - & 5558 & $\mathrm{MS}, \mathrm{OP}$ & $23,180 \pm 1280$ & $40^{\circ} 18^{\prime} \mathrm{S}$ & $147^{\circ} 52^{\prime} \mathrm{E}$ & Sim 1998, Cosgrove 1999 \\
\hline DRS 7 & - & + & + & - & DRS7 & 4057 & $\mathrm{OP}$ & $3960 \pm 60$ & $42^{\circ} 20^{\prime} \mathrm{S}$ & $146^{\circ} 44^{\prime} \mathrm{E}$ & Garvey 1999 \\
\hline Permerpar Meethaner & - & + & - & - & - & 4434 & $\mathrm{MS}, \mathrm{OP}$ & $33,850 \pm 450$ to $33,280 \pm 420$ & $41^{\circ} 42^{\prime} \mathrm{s}$ & $146^{\circ} 05^{\prime} \mathrm{E}$ & Cosgrove 1995,1999 \\
\hline Mackintosh Cave & - & + & - & - & LM90/1 & 4551 & MS & $17,030 \pm 430$ to $14,820 \pm 140$ & $41^{\circ} 43^{\prime} \mathrm{S}$ & $145^{\circ} 40^{\prime} \mathrm{E}$ & $\begin{array}{l}\text { McNiven et al. } 1993 \text {, Stern \& Marshall } 1993 \text {, } \\
\text { McWilliams et al. } 1999\end{array}$ \\
\hline Nunamira Cave & + & + & + & $\mathrm{JF}-53$ & - & 4046 & OP & $30,750 \pm 1340$ to 11,600 & $42^{\circ} 37^{\prime} \mathrm{S}$ & $146^{\circ} 26^{\prime} \mathrm{E}$ & $\begin{array}{l}\text { Cosgrove 1991, 1996a, McNiven et al. } 1993 \text {, } \\
\text { Cockbill 1999, McWilliams et al. 1999; Garvey } \\
\text { unpubl. data }\end{array}$ \\
\hline ORS 7 & - & - & + & - & ORS 7 & 2089 & OP & $30,840 \pm 480$ to $2,450 \pm 70$ & $42^{\circ} 05^{\prime} \mathrm{S}$ & $146^{\circ} 50^{\prime} \mathrm{E}$ & $\begin{array}{l}\text { Cosgrove et al. } 1990 \text {, Cosgrove 1991, 1996b, } \\
\text { McWilliams et al. } 1999\end{array}$ \\
\hline Bone Cave & + & + & - & - & - & 1790 & MS & $29,000 \pm 520$ to $13,700 \pm 860$ & $42^{\circ} 50^{\prime} \mathrm{S}$ & $146^{\circ} 27^{\prime} \mathrm{E}$ & $\begin{array}{l}\text { Goede \& Bada 1985, Northwood 1990, McNiven } \\
\text { et al. 1993, Allen 1996, McWilliams et al. } 1999\end{array}$ \\
\hline Pseudocheirus Cave & + & + & - & IB-97 & - & - & $\mathrm{OP}, \mathrm{PF}$ & 12,800 to 400 & $43^{\circ} 10^{\prime} \mathrm{S}$ & $146^{\circ} 40^{\prime} \mathrm{E}$ & Clarke 1988a, Muirhead 1990 \\
\hline March Fly Pot & + & + & - & IB-46 & - & - & $\mathrm{PF}$ & 12,800 to 400 & $43^{\circ} 10^{\prime} \mathrm{S}$ & $146^{\circ} 40^{\prime} \mathrm{E}$ & Muirhead 1990 \\
\hline Warhol & - & + & - & JF-392 & - & - & PF & Holocene-Recent & $42^{\circ} 42^{\prime} \mathrm{S}$ & $146^{\circ} 30^{\prime} \mathrm{E}$ & Eberhard 1988 \\
\hline Warreen & + & + & - & - & $M-86 / 2$ & 3786 & $\mathrm{OP}$ & $34,790 \pm 510$ to $15,960 \pm 310$ & $42^{\circ} 37^{\prime} \mathrm{S}$ & $145^{\circ} 55^{\prime} \mathrm{E}$ & $\begin{array}{l}\text { Allen et al. 1989, McNiven et al. 1993, Cockbill } \\
\text { 1999, McWilliams et al. } 1999\end{array}$ \\
\hline Main Drain & - & + & - & BH-8 & - & - & $\mathrm{PF}$ & Holocene-Recent & $42^{\circ} 07^{\prime} \mathrm{S}$ & $145^{\circ} 46^{\prime} \mathrm{E}$ & Clarke 1988b, 1989 \\
\hline Newdegate Cave & + & + & - & $\mathrm{H}-1$ & - & - & OP & Holocene-Recent & $43^{\circ} 22^{\prime} \mathrm{S}$ & $146^{\circ} 50^{\prime} \mathrm{E}$ & Clarke 1999, 2000 \\
\hline Kutikina Cave & + & & - & F-34 & - & 485 & $\mathrm{OP}$ & $19,770 \pm 850$ to $14,840 \pm 930$ & $42^{\circ} 31^{\prime} \mathrm{S}$ & $145^{\circ} 46^{\prime} \mathrm{E}$ & Garvey 2006 \\
\hline $\begin{array}{l}\text { Geilston Bay } \\
\text { (Cercartetus-like sp) }\end{array}$ & - & - & $?$ & - & - & - & - & $23 \mathrm{Ma}$ & $42^{\circ} 50^{\prime} \mathrm{S}$ & $147^{\circ} 21^{\prime} \mathrm{E}$ & Tedford \& Kemp 1998 \\
\hline
\end{tabular}

$\mathrm{Cl}=$ C. lepidus, $\mathrm{Cn}=$ C. nanus, Csp. $=$ Cercartetus sp. KI code $=$ Karst Index alphanumeric code assigned to the respective caves by the Australian Speleological Federation. Site Code $=$ Identification codes assigned by individual research groups. TASI code = Tasmanian Aboriginal Site Index. Origin: OP = Owl Pellet, MS = Mammal Scat, PF= Pitfall. A dash ( - ) indicates that the data are unknown or not available. The age of the material is years before present (yr BP) provided by the source indicated. Ma = Millions of years ago. 


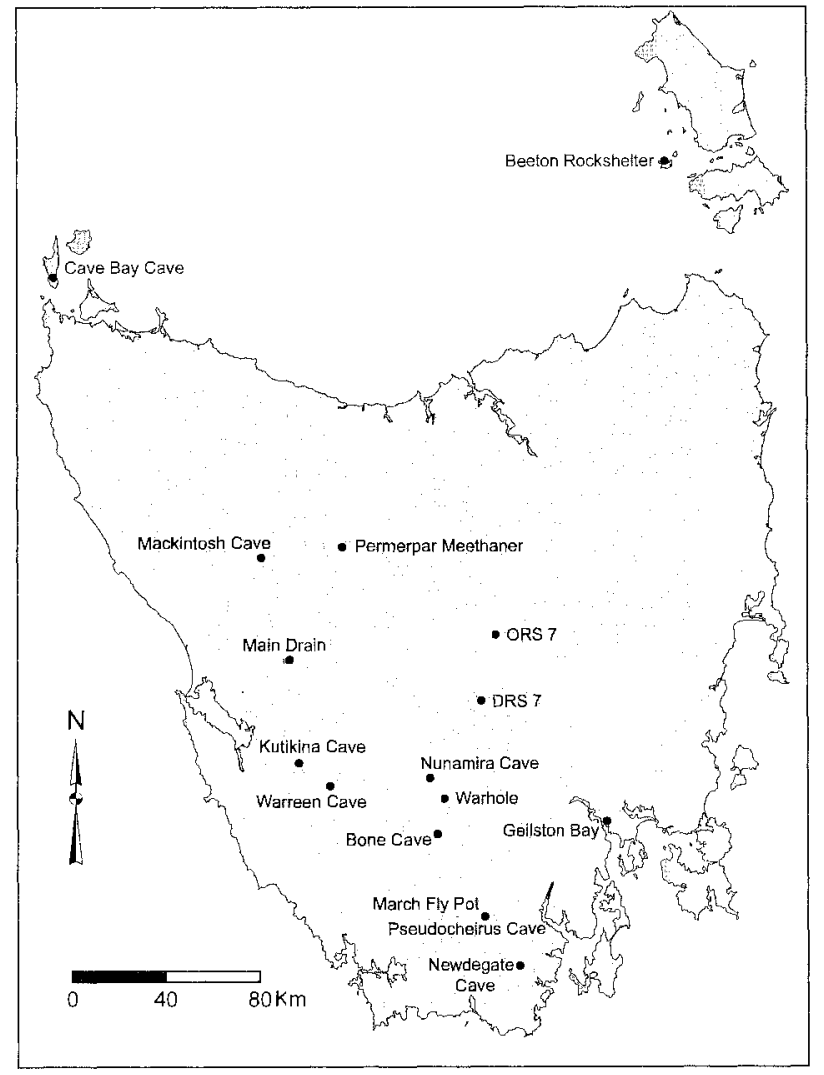

FIG. 1 - Late Pleistocene andlor Holocene fossil sites for Cercartetus in Tasmania.

bone fragments of Cercartetus spp. ("pygmy-possum; species unknown") were recorded. Cosgrove (1991) explained that no attempt was made to separate $C$. lepidus and $C$. nanus because of their similarity. Mackintosh Cercartetus material included mandibles, maxilla and long bones (humerus, radius, ulna, tibia), and were collected from square/spits designated as HN7 (IDs=1015, 1046, 1071; 1072; 1073), GO4 (ID=7455), HM13 (ID=10871) and GL5 (IDs=1940; $1941 ; 1942 ; 1968)$. For Numamira, the database contained 14 entries for "Cercartetus spp." representing 28 mandibles or maxillae (all from Square A1, Cell Z, spits 1-7, and Square B1, Cell W, spits 5-7). The Nunamira material is held by TALSC and recent examination of some of this collection allowed verification of the presence of both $C$. nanus and C. lepidus (J. Garvey unpubl. data). For ORS 7 , only two mandibles of "Cercartetus spp." were recorded on the database, from Square B1, spit 6. For Warreen, there were 62 elemental specimens of $C$. lepidus, and 71 of $C$. nanus. The Warreen pygmy-possum bones excavated are mainly left and right mandibles, but also include various other skeletal elements. At Warreen, C. lepidus was collected from Square A (spits 11 and 16) and Square B (spits 32, 35, 42-45, 47-58, 60 and 61). The Warreen C. nanus was collected from Square A (spits 8, 10, 11-17, 19) and Square B (spits 32, 42, 46, 50, 52, 53, 55, 56, and 59) (see McWilliams et al. 1999).

Large mammal bones, particularly those of Macropus and Vombatus, were found in large numbers during archaeological studies of several of the caves referred to, and are thought to have been accumulated by humans (see Jones 1990, Cosgrove et al. 1990, Stern \& Marshall 1993, Cosgrove 2002; Garvey 2006). However, owls and marsupial carnivores are the principal accumulators of the majority of small mammal species, nothwithstanding that pitfalls have also accumulated significant numbers.

For Cave Bay Cave, Bowdler (1974b:698, 1984:88) attributed the accumulation of Cercartetus material (and also Antechinus and murids) to owls, "with the masked owl (Tyto novaehollandiae) considered the most likely candidate". Remains of larger mammals in this deposit were attributed to accumulation by Tasmanian devils (Sarcophilus harrisii), quolls (Dasyurus spp.) or humans. For Nunamira, Cosgrove (1991:260) stated that "the most likely source of [the small mammal] bone was regurgitated owl pellets", noting several hollows in the roof of Nunamira, which "would serve well as owl roosts". Cosgrove (1991) did not speculate on the identity of the owl species involved, but in subsequent publications it has been suggested that owls of the genus Tyto were responsible (e.g., McNiven et al. 1993).

For ORS 7, Cosgrove (1991:299) favoured owl predation as the most likely explanation for accumulation of Cercartetus and other small mammal remains because the bone was in "relatively good condition". For Warreen, owl-pellet bone is most common in the lower levels of the deposit (McNiven et al. 1993). For Bone Cave, fossil material recovered was highly fragmented and generally consistent with damage caused by marsupial carnivores (Northwood 1990, McNiven et al. 1993, Stern \& Marshall 1993). Northwood (1990) believed that the eastern quoll Dasyurus viverrinus was responsible for the accumulation of small mammal remains in Bone Cave, which was supported by the discovery of $D$. viverrinus bones in the assemblage. Based on the size range of the bone fragments McNiven et al. (1993) agreed that D. viverinnus was primarily responsible, although it was noted that Sarcophilus harrisii may also have contributed some scat remains at this site. For Mackintosh Cave, Stern \& Marshall (1993) implicated D. maculatus, stating that faunal composition and their relative abundances compared favourably with its diet. Further support for this conclusion came from the pattern of surface damage observed on the bones of the prey species, which was more characteristic of $D$. maculatus than it was of $S$. harrisii (also see Marshall $\&$ Cosgrove 1990). However, bones from larger prey species present in the assemblage may have been the result of the activity of $S$. harrisii (McNiven et al. 1993, Stern \& Marshall 1993).

For Beeton Rockshelter, Sim (1998) suggested that most terrestrial bones recovered fit the criteria for $S$. harrisii scat remains (following Marshall \& Cosgrove 1990). However, Sim (1998:150) noted that the "murid and possibly other small mammal bones most probably originate from owls roosting and raptors perching in the shelter, although quolls may also be responsible for a component". At Permerpar Meethaner, most bone can be attributed to marsupial carnivore activity and this is supported by the discovery of old coprolitic material and of tooth marks on some bones. However, remains of smaller mammals in the lower portion were thought to be derived from owl pellet deposition (Cosgrove 1995). Warhol is a pitfall trap, and the small mammal temains present (including C. lepidus) are thought to have accumulated via an "abrupt shaft with vertical and overhanging walls" (Eberhard 1988:53). March Fly Pot was probably also a pitfall for Cercartetus (Muirhead 1990). The Cercartetus in Pseudocheirus Cave are thought to have been first accumulated by owls and then "washed from an owl deposit at a higher region of the cave before being deposited" (Muirhead 1990:18). However, this cave has nearly vertical walls, and because suitable owl roosting 
alcoves are absent, it is more likely these remains accumulated from pitfalls (A. Clarke pers. comm. 2006). At DRS 7, Garvey (1999) found that owls accumulated the small mammals, but post-depositional effects prevented the identification of the species of owl.

The fossils from Badger Island (Beeton Rockshelter) and Hunter Island (Cave Bay Cave) are Late Pleistocene in age, dating to 24-21 ka (ka= thousand years ago) and 22-18 ka respectively (table 1 ). Most mainland Tasmanian sites for fossil pygmy-possums are also Late Pleistocene and span 35-12 ka, including bones collected from Warreen (35-15 ka), Peramerpar Meethaner (34-32 ka), Nunamira (32-12 ka), Bone Cave (30-13 ka), Kutikina Cave (20-14 ka) and Mackintosh Cave (16-15 ka). The ORS 7 site (31-2 ka) incorporated both Late Pleistocene and Holocene material. This is probably also true for March Fly Pot and Pseudocheirus Cave, which were inferred to be around 13-0.4 ka. There are also three undated deposits (Warhol, Main Drain, and Newdegate Cave) that are thought to be of Holocene to recent age. The other sites are the Holocene assemblage at DRS 7 ( $4 \mathrm{ka}$ ) and the Geilston Bay Oligocene material $(-23 \mathrm{Ma})$.

\section{DISCUSSION}

With impacts of climate change on biota thought to be rapidly increasing (Hughes 2003), detailed understanding of prehistoric ranges is important, particularly for those species like Burramys that are suggested to be at risk of climate-induced extinction (Mansergh \& Broome 1994). OfTasmanian material that can be confidently assigned to Cercartetus, the dated ages range from $3960 \pm 60$ years (y) (DRS 7) to 34,790 $\pm 510 y$ (Warreen) (table 1). However, the reliability of the radiocarbon $\mathrm{C}^{14}$ dating (table 1 ) requires comment. The Cave Bay Cave date $(22,750 \pm 420 \mathrm{y})$ is one of a sequence of four dates between 14 and $23 \mathrm{ka}$ that apparently agree well with stratigraphic and chronological evidence (Murray et al. 1980 , Goede \& Bada 1985). The series of dates for other sites are mostly, but not invariably, in stratigraphic order (see Cosgrove 1989, 1995, Stern \& Marhall 1993, Jones 1995, Allen 1996). The concurrence of around $120 \mathrm{C}^{14}$ dates across seven sites (McWilliams et al. 1999) suggests that the chronology is an accurate and robust reflection of events. Nevertheless, because $\mathrm{C}^{14}$ dating of samples can be subject to various errors (Goede \& Bada 1985, Baynes 1999), all the dates reported here should be treated with caution. Corroboration with other dating methods, such as electron spin resonance (ESR), amino acid racemisation (AAR), thermo-luminscence (TL) and uranium-series (see Goede \& Bada 1985, Prescott \& Robertson 1997, Ayliffe \& Veeh 1998, Grün et al. 2001) would impart greater confidence in these $\mathrm{C}^{14}$ dates.

\section{Identification of the predatory accumulators}

Several criteria have been established to differentiate an owl deposit from a mammalian carnivore deposit. In owl deposits the remains of small animals dominate; the largest animals are represented by juveniles; whole skulls and other skeletal elements are represented; and there is only modest fragmentation of the bone (see also Dodson \& Wexlar 1979, Marshall 1986, Andrews 1990, Geering 1990, Kusmer 1990, Garvey 1999). In contrast, high fragmentation tates are characteristic of S. harrisii and Dasyurus sp. coprolites
(Marshall \& Cosgrove 1990, Northwood 1990, Garvey 1999). Using these criteria, owls have been implicated as the main accumulator of small mammals at six sites - i.e., DRS 7, Kutikina Cave, Newdegate Cave, Nunamira, ORS 7 and Warreen (table 1). In contrast, at Mackintosh Cave and Bone Cave, mammalian predators were identified as the principal accumulators. At Cave Bay Cave, Beeton Rockshelter and Permerpar Meethaner, there is evidence for both avian and mammalian accumulators. However, identification of the specific predatory species involved at each of these cave sites remains ambiguous.

The Tasmanian Masked Owl Tyto castanops, Barn Owl T. alba and Southern Boobook Ninox novaeselandiae can be nominated as possible avian accumulators, as these are the only owls known to have lived in Tasmania during the Late Holocene (Garvey 1999), and probably during the Late Pleistocene. Possible dasyurid accumulators were the Spotted-tailed Quoll D. maculatus, Eastern Quoll D. viverrinus, Tasmanian Devil S. harrisii and/or Tasmanian Tiger Thylacinus cynocephalus. Except for T. cynocephalus, there are numerous records for Cercartetus falling prey to these predators (see Guiler 1970, Wallis et al. 1977, Green $e t$ al. 1986, Mooney 1992, 1993, Mumbray 1992, McNabb et al. 2005). Thylacinus cynocephalus was a large predator, now believed extinct, which fed mainly on large animals such as kangaroos and wallabies (Menkhorst \& Knight 2001). Hence, it seems reasonable to eliminate $T$. cynocephalus as the accumulator of the small mammal material in Tasmanian cave deposits on the basis that they were unlikely to take such small prey. Although it is possible that $N$. novaeseelandiae contributed a small amount of vertebrate bone to one or more assemblages, it is unlikely that this species was a significant contributor because of its generally insectivorous diet. Precise identification of the predatory species involved at each of the cave sites referred to may be possible at a future date, by using microscopy to search for diagnostic taphonomic signatures such as digestive corrosion patterns or tooth markings, or by quantative re-assessment of skeletal element representation and breakage (see also Northwood 1990, Garvey 1999, McWilliams et al. 1999, Harris \& Goldingay 2005b). We also emphasise that further research is needed on the taphonomy of pitfall-originated Cercartetus remains, focusing particularly on identifying criteria which allow their differentiation from predator deposits.

\section{Past and present distribution of pygmy- possums in Tasmania}

The antiquity of the burramyid fossil record in Tasmania (Tedford \& Kemp 1998) raises the intriguing possibility that pygmy-possums may have evolved in Tasmania and dispersed to mainland Australia. Conversely, members of this genus may have arrived in Tasmania via the mainland. If the latter hypothesis is correct, Cercartetus probably followed the same route as the Aboriginal Tasmanians - across exposed portions of a Bassian land bridge connecting Wilson's Promontory, Flinders Island and northeast Tasmania (Cosgrove 1999). It is calculated that this bridge existed at $55-50 \mathrm{ka}$, and again at $37-31 \mathrm{ka}$ and most recently at 29-12 ka (Blom 1988, Jones 1995, Cosgrove 1999). However, it is not known how long Cercartetus has resided in Tasmania and whether populations migrated during any or all of these alternating periods of land connection and isolation. Present evidence suggests that $C$. nanus and C. lepidus were both present in southwest 
Tasmania as long ago as $35 \mathrm{ka}$ (Warreen). However, the oldest Cercartetus fossils from the mainland are dated to $279 \mathrm{ka}$ (Cathedral Cave, at Naracoorte, in southeast SA; Reed \& Bourne 2000, Harris in press). This raises questions concerning the palaeobiogeography and migration of this genus, but further data including re-assessment of radiocarbon dates are needed (see above).

Of particular relevance to future research is the effect of major climatic and vegetational changes on faunal associations in Tasmania during the Late Pleistocene (e.g., MacPhail 1975, Bowler et al. 1976, Colhoun 1978, Hope 1978, Jones 1984, 1990, 1995, Augustinas \& Colhoun 1986, Cosgrove et al. 1990, Colhoun et al. 1991, Jordan et al. 1991, Kirkpatrick \& Fowler 1998, Cosgrove 1999, Reid et al. 1999). Currently, based on palynological evidence, it appears that before $45 \mathrm{ka}$, the Tasmanian vegetation consisted mainly of alpine and subalpine taxa and the forested environments were confined to low altitudes. Cercartetus spp. do not tolerate terestrial alpine and treeless subalpine habitats in Tasmania today (Kirkpatrick et al. 1993), and so may have had a restricted (or non-existent) distribution in Tasmania prior to $45 \mathrm{ka}$. Between 44 and $25 \mathrm{ka}$, the climate was still colder and wetter than today, but in this period Cercartetus is known from numerous sites from south-west Tasmania. Cercartetus appears to be present in the vicinity of several sites at the height of the last glacial $(-18 \mathrm{ka})$, but populations were probably not abundant or widespread until the onset of warmer and wetter conditions at about $12 \mathrm{ka}$. The two species are widespread in the southwest region in modern times, with the habitat of $C$. nanus today regarded as "rainforest" and for C. lepidus as "dry sclerophyll forest and heathland" (Hocking 1979). However, modern populations do overlap (see range maps in Munks et al. 2004) and there is also evidence for this in prehistoric times (i.e., in the vicinity of Cave Bay Cave, Beeton Rockshelter, Bone Cave, Pseudocheirus Cave, March Fly Pot, and Nunamira) (table 1).

Cercartetus is recorded on Hunter Island for the period $22-$ $18 \mathrm{ka}$, and populations may have become established there at the time of the most recent $(29-12 \mathrm{ka})$ or penultimate (37-31 ka) landbridge. The same may be true for Cercartetus on Badger Island (24-21 ka). Modern populations of Cercartetus are not recorded from the Hunter Island group (Bowdler 1984) or from Badger Island (Sim 1998), but one or both species could still occur there, as intensive mammal surveys have not been conducted. Munks et al. (2004) noted the presence of extant burramyid populations on the larger land-bridge fragments of King Island $(C$. nanus) and Flinders Island (C. lepidus and C. nanus) (see also Hope 1973). Surveys for pygmy-possums are needed on these smaller islands to discern whether populations are now truly extinct.

The distribution of fossil sites for Cercartetus in Tasmania is shown in fig. 1. It is not yet possible to confidently delimit separate maps for $C$. lepidus and $C$. nanus, as discrimination of these two species on the basis of dental and other skeletal material requires specialist attention and the specific identity of many of these fossils needs to be reassessed (see also Green \& Rainbird 1983, Garvey 1999). Nevertheless, the map of fossil Cercartetus sites in Tasmania does indicate that the genus had a broad distribution in the Late Pleistocene. We caution that fig. 1 is essentially a reflection of the distribution of cave sites where detailed excavations have taken place. Most of the sites are caves situated in the southern, southwestern, and western areas of Tasmania. In this region there are extensive tracts of karstic carbonate rock (mainly Silurian and Ordovician limestone and Cambrian/ Precambrian dolomites) and these older geological formations are apparently rare in the eastern regions of Tasmania, which may explain the relative paucity of Cercartetus fossils outside of the southwest. Obviously, the perceptible palaeodistribution of Cercartetus in Tasmania (and on mainland Australia) is restricted to suitable areas where conditions allow the preservation of delicate skeletal material (i.e., in caves and protected rockshelters), where stable climatic conditions prevail with near constant humidity. The collection of pygmy-possum material also requires careful excavation and small sieve sizes; otherwise their bones are likely to be lost (Hall 1975). They may be easily overlooked, especially when the focus of a fossil investigation is on larger taxa. Notwithstanding these potential sources of preservation and collection bias, compatison of Quaternary and present distributions suggest that there are apparently no regions where Cercartetus was, but is no longer, found on mainland Tasmania.

Our review of published literature indicates that pygmypossums were not found among the mammal fossils excavated at a number of sites throughout Tasmania, including at Prion Beach Rockshelter in far southern Tasmania (2070 \pm 70 Dunnett 1992); Flowery Gully (7080 \pm 420 ; Gill 1968); Tiata Mara Kominya (formerly Beginners Luck Cave) $(80,000$ to $12,600+200$; Goede et al. 1978 , Murray 1979 Murray et al. 1980, Bowdler 1982, Allen 1996, Goede \& Bada 1985); Pleisto Scene Cave $(130,000$ to $10,100 \pm 200$; Murray \& Goede 1977, Goede et al. 1978, Goede \& Bada 1985); Cardia Cave (18,000; Jones \& Allen 1984); Pallawa Trounta (formerly Acheron Cave) $(29,800 \pm 720$ to 13,000 ; McNiven et al. 1993, McWilliams et al. 1999); Maneena Langatick Tattana Emita $(10,250 \pm 420$; Pocock 1992, 1993); Mannalargenna Cave $(20,560 \pm 290$ to $7,960 \pm 170$; Brown 1993); Louisa Bay (Vanderwal 1979); Stone Cave (16,670 70; McWilliams et al. 1999); Warragarra Rockshelter $(10,910 \pm 110$ to $410 \pm 60 ; \mathrm{McWilliams}$ et al. 1999), or Titans Shelter (27 ka) (Goede \& Murray 1979 , Cosgrove et al. unpubl. data). The reason why burramyid bones were not reported from these caves is unknown. They may have been absent or too small to be detected in the excavations. The majority of these caves were used as roost sites for owls or den sites for dasyurids so it is expected that Cercartetus could be present. There are also a number of vertical (pitfall) caves with significant sub-fossil deposits of currently unstudied mammalian remains in the Bubs Hill, Cracroft, Hastings, Ida Bay, Junee-Florentine, Mole Creek, Mount Weld and Precipitous Bluff karst areas in Tasmania (A. Clarke pers. comm. 2006).

There are also many other caves known to contain mammal bone, but thus far only very small samples have been collected from the surface layers of these sites, and at present Cercartetus is not recorded. Such localities include Nanwoon Cave (7.2 ka); Main Cave, Montagu (13 ka); Boomer Cave (20 ka); Un-named Cave, Florentine Valley (97 ka); Nelson River Cave (19 ka); and Deena Reena Cave (19 ka) (Goede et al. 1978; Kiernan 1982; Goede \& Bada 1985; Jones 1995; see also Andrews 1971). There are conservatively about 2800 other caves within Tasmania (Clarke 2005; see also Middleton 1979; Kiernan 1988; Jones 1995), but only a small number of these have been subjected to archacological or palaeontological study. 


\section{CONCLUSION}

This paper provides a preliminary account of Tasmanian burramyid biogeography and highlights the need for more detailed palaeontological and archaeological study of caves and rockshelters throughout Tasmania. Further research should involve re-examination of the ORS 7 material to ascertain whether the Cercartetus specimens represent C. lepidus, $C$. nanus, or both species. Calculation of dates for the faunal assemblages from Warhol, Main Drain and Newdegate Cave would also be desirable. The excavation of new localities is imporrant because "new" fossil pygmy-possum material may be discovered, providing further information on the palaeodistibution of these species. Finding new fossil localities for C. lepidus and C. nanus in northwestern and northeastern Tasmania would be particularly valuable, as would additional specimens of Tedford \& Kemp's (1998) undescribed Cercartetus-like species; additionally, it is entirely possible that Burramys (see Long et al. 2002) may yet be found in Tasmanian cave deposits.

\section{ACKNOWLEDGEMENTS}

For information and advice we thank Sandra Bowdler (University of Western Australia), Arthur Clarke (University of Tasmania), Rolan Eberhard (Tasmanian Department of Primary Industries, Water and Environment), Ross Goldingay (Southern Cross University), Noel Kemp (Tasmanian Museum and Art Gallery), and Caleb Pedder and Don Ranson (Aboriginal Heritage Office, Tasmanian Department of Tourism, Parks, Heritage and the Arts). We are also grateful to Greg Luker (Southern Cross University) for producing the figure, and to Richard Cosgrove (La Trobe University), John Long (Museum Victoria) and Kristofer Helgen (University of Adelaide) for commenting on an earlier version of the manuscript.

\section{REFERENCES}

Aitken, P.F. 1967: Cercartetus lepidus (Thomas) an addition to the fauna of Kangaroo Island. Records of the South Australian Museum 15: 575-576.

Aitken, P.F. 1974: The little pigmy possum Cercartetus Lepidus (Thomas) on Kangaroo Island, South Australia. The South Australian Naturalist 48: 36-43.

Aitken, P.F. 1977: The little pigmy possum Cercartetus lepidus (Thomas) found living on the Australian mainland. The South Australian Naturalist 51: 63-66.

Allen, J. (ed) 1996: Report of the southern forests archaeological project. Volume 1. Site descriptions, stratigraphies and chronologies. School of Archacology, La Trobe University: 277 pp.

Allen, J., Marshall, B. \& Ranson, D. 1989: A note on excavations at the Maxwell River site, M86/2, southwest Tasmania. Australian Archaeology 29: 3-8.

Andrews, A.P. 1971. Cave bones in Tasmania. Australian Speleological Federation Newsletter 51: 14-16.

Andrews, P. 1990: Owls, Caves and Fossils. Natural History Museum Publications, London: $231 \mathrm{pp}$.

Archer, M. 1974: New information about the Quaternary distribution of the Thylacine (Marsupialia: Thylacinidae) in Australia. Journal and Proceedings of the Royal Society of Western Australia 57: 43-50.

Archer, M., Hand, S.J. \& Godthelp, H. 1991: Back to the future: the contribution of palaeontology to the conservation of
Australian forest fauna. In Lunney, D. (ed.): Conservation of Australia's Forest Fauna. Royal Zoological Society of New South Wales and Surrey Beatty and Sons Pty Ltd, Chipping Norton, New South Wales: 67-80.

Augustinas, P. \& Colhoun, E.A. 1986: Glacial history of the upper Pieman and Boco valleys, western Tasmania. Australian Journal of Earth Sciences 33: 181-191.

Ayliffe, L.K. \& Veeh, H.H. 1998: Uranium-series dating of speleothems and bones from Victoria Cave, Naracoorte, South Australia. Chemical Geology (Isotope Geoscience Section) 72: 211-234.

Baird, R.F. 1991: The taphonomy of late Quaternaty cave localities yielding vertebrate remains in Australia. In Vickers-Rich, P., Monaghan, J.M., Baird, R.F. \& Rich, T.H. (eds): Vertebrate Palaeontology of Australasia. Monash University, Melbourne: 267-309.

Baynes, A. 1987: The original mammal fauna of the Nullarbor and Southern Peripheral Regons: Evidence from skeletal remains in superficial cave deposits. In McKenzie, N.L. \& Robinson, A.C. (eds): A Biological Survey of the Nullarbor Region South and Western Australia in 1984. South Australian Department of Environment and Planning, Adelaide: 139-152, 400-401.

Baynes, A. 1999: The absolutely last remake of Beau Geste: yet another review of the Australian megafaunal radiocarbon dates. Records of the Western Australian Museum Supplement 57: 391.

Baynes, A. \& Johnson, K.A. 1996: The contributions of the Horn Expedition and cave deposits to knowledge of the original mammal fauna of central Australia. In Morton, S.R. \& Mulvaney, D.J. (eds): Exploring Central Australia, the Environment and the 1894 Horn Expedition. Surrey Beatty and Sons, Chipping Norton: 168-186.

Blom, W.M. 1988: Late Quaternary sediments and sea-levels in Bass Basin, southeastern Australia - a preliminary report. Search 19: 94-96.

Bowdler, S. 1974a: An account of an archaeological reconnaissance of Hunter's isles, north-west Tasmania, 1973/4. Records of the Queen Victoria Museum 54: 1-32.

Bowdler, S. 1974b: Pleistocene date for man in Tasmania. Nature 252: 697-698.

Bowdler, S. 1975: Further radio-carbon dates from Cave Bay Cave, Hunter Island, north-west Tasmania. Australian Archaeology Association Newsletter 3: 24-26.

Bowdler, S. 1982: Prehistoric archaeology in Tasmania. In Wendorf, F. \& Close, A.E. (eds): Advances in World Archaeology. Volume 1. Academic Press, New York: 1-49.

Bowdler, S. 1984: Hunter Hill, Hunter Island: archaeological investigations of a prehistoric site. The Australian National University, Canberra: $148 \mathrm{pp}$.

Bowen, M. \& Goldingay, R. 2000: Distribution and status of the eastern pygmy possum (Cercartetus nanus) in New South Wales. Australian Mammalogy 21: 153-164.

Bowler, J.M., Hope, G.S., Jennings, J.N., Singh, G. \& Walker, D. 1976: Late Quaternary climates of Australia and New Guinea. Quaternary Research 6: 359-394.

Brammall, J. 1993: From sauna to snowfields - from Riversleigh to Kosciusko. A story about Burramys. Riversleigh Notes 23: 2-5.

Broome, L.S. \& Mansergh, I.M. 1989: The Mountain Pygmy Possum, Burramys parvus (Broom): an alpine endemic. In Good, R. (ed.): The Scientific Significance of the Australian Alps. The Australian Alps National Parks Liaison Committee/Australian Academy of Science, Canberra: 241-264.

Brown, S. 1993: Mannalargenna Cave: a Pleistocene site in Bass Strait. In Smith, M.A., Spriggs, M. \& Fankhauser, B. (eds): Sabul in review: Pleistocene Archaeology in Australia, New Guined and Island Melanesia. Department of Prehistory, Research School of Pacific Studies, Australian National University, Canberra: 258-271. 
Carthew, S.M. 2004: Distribution and conservation status of possums and gliders in South Australia. In Goldingay, R.L. \& Jackson, S.M. (eds): The Biology of Australian Possums and Gliders. Surrey Beatcy and Sons, Chipping Norton: 63-70.

Clarke, A. 1988a: The biology of caves in southern Tasmania. Tasmanian Cave and Karst Research Group Journal 3: $18-29$.

Clarke, A. 1988b: Fauna from the Bubs Hill Karst, W. Tasmania. Report to Department of Lands, Parks and Wildlife, Tasmania. $31 \mathrm{pp}$.

Clarke, A. 1989: Fauna from the caves and karsts of the Bubs Hill area, Western Tasmania. Report to Tasmanian Department of Parks, Wildlife and Heritage, July 1989. 24 pp.

Clarke, A. 1999: Cave fauna interpretation: Hastings karst (Newdegate Cave). Speleo Speil: Newsletter of the Southern Tasmanian Caverneers Inc 314 (June-July 1999): 11-13.

Clarke, A. 2000: Owl pellet remains in Newdegate Cave (H-X7) southern Tasmania. Cave Queensland 22nd Biennial Conference - Australian Speleological Federation 1999 Conference Proceedings: 26-36.

Clarke, A. 2005: An overview of cave areas and the invertebrate cave fauna in Tasmania. In Goede, A. \& Bunton, S. (eds): Cave Mania 2005 Proceedings: Downunder at Dover. 25th Biennial Conference of the Australian Speleological Federation: 10

Cockbill, J. 1999: Bones of contention, Unpublished BA Hons thesis, Department of Archaeology, La Trobe University, Melbourne.

Colhoun, E.A. 1978: The late Quaternary environment of Tasmania as a backdrop to man's occupance. Records of the Queen Victoria Museum 61: 1-11.

Colhoun, EA, van der Geer G, \& Hannan, D. 1991: Late glacial and Holocene vegetation history at Dublin Bog, north-central Tasmania. Australian Geographical Studies 29: 337-354.

Cosgrove, R. 1989: Thirty thousand years of human colonization in Tasmania: new Pleistocene dates. Science 243: $1706-1708$.

Cosgrove, R. 1991: The illusion of riches: issues of scale, resolution and explanation of Pleistocene human behaviour. PhD thesis. La Trobe University, Melbourne.

Cosgrove, R. 1995: Late Pleistocene behavioural variation and time trends: the case from Tasmania. Archaeology in Oceania 30: 83-104.

Cosgrove, R. 1996a: Nunamira Cave. In Allen, J. (ed.): Report of the Southern Forests Archaeological Project. Volume 1. Site descriptions, stratigraphies and chronologies. School of Archaeology, La Trobe University: 43-68.

Cosgrove, R. 1996b: ORS 7 Rockshelter. In Allen, J. (ed.): Report of the Southern Forests Archaeological Project. Volume 1. Site descriptions, stratigraphies and chronologies. School of Archaeology, La Trobe University: 69-89.

Cosgrove, R. 1999: Forty-two degrees south: the archaeology of Late Pleistocene Tasmania. Journal of World Prehistory 13: $357-402$.

Cosgrove, R. 2002: The role of zooarchaeology in archaeological interpretation: a view from Australia. Archaeofauna 11: 173-204.

Cosgrove, R., Allen, J. \& Marshall, B. 1990: Paleo-ecology and Pleistocene human occupation in south-central Tasmania. Antiquity 64: 59-78.

Dodson, P. \& Wexlar, D. 1979: Taphonomic investigations of owl pellets. Paleobiology 5: 275-284.

Duncan, A.M.R. \& Taylor, R.J. 2001: Occurrence of pygny possums, Cercartetus lepidus and C. nanus, and their nest sites in logged and unlogged dry and wet eucalypt forest in Tasmania. Australian Forestry 64: 159-164.

Dunnett, G. 1992: Prion beach rockshelter: seabirds and offshore islands in southwest Tasmania. Australian Archaeology 34: $22-28$.
Eberhard, S. 1988: Record of mammalian remains from a cave in the Florentine Valley. Tasmanian Cave and Karst Research Group Journal 3: 53-57.

Garvey, J. 1999: Taphonomic analysis of the small vertebrate fauna from the archaeological site Derwent River Shelter 7 (DRS7), Tasmania. Unpublished Hons thesis. Departments of Zoology and Archaeology, La Trobe University.

Garvey, J. 2006: Preliminary zooarchaeological interpretations from Kutikina Cave, southwest Tasmania. Australian Aboriginal Studies 2006/1.

Geering, K. 1983: Preliminary analysis of the faunal remains from Kutikina Cave, Franklin River, 1981 Excavation. Unpublished report to the Tasmanian Parks and Wildlife Service, Hobart, 25 pp.

Geering, K. 1990: Taphonomic analysis of Masked Owl pellets in Tasmania. In Solomon, S., Davidson, I. \& Watson, D. (eds): Problem Solving in Taphonomy. Anthropology Museum, University of Queensland, Brisbane: 135-148.

Gill, E.D. 1968: Aboriginal bone implement from fossil bone bed, Tasmania. Records of the Queen Victoria Museum 31: $1-4$.

Goede, A. \& Bada, J.L. 1985: Electron spin resonance dating of Quaternary bone material from Tasmanian caves - a comparison with ages determined by aspartic acid racemization and $\mathrm{C}^{14}$. Australian Journal of Earth Sciences 32: $155-162$.

Goede, A. \& Murray, P. 1979: Late Pleistocene bone deposits from a cave in the Florentine Valley, Tasmania. Papers and Proceedings of the Royal Society of Tasmania 113: 39-52.

Goede, A., Murray, P. \& Harmon, R. 1978: Pleistocene man and megafauna in Tasmania: dated evidence from cave sites. The Artifact 3: 139-149.

Green, R.H. 1973: The mammals of Tasmania. Foot and Playsted, Launceston: 20-21.

Green, R.H. 1979: The Little Pigmy Possum Cercartetus lepidus in Tasmania. Records of the Queen Victoria Museum 68: $1-12$.

Green, R.H. 1983: Little Pygmy-possum Cercartetus lepidus. In Strahan, R. (ed.): The Complete Book of Australian Mammals. Angus and Robertson, Sydney: 164-165.

Green, R.H. \& Rainbird, J.L. 1983: An illustrated key to the skulls of mammals in Tasmania. Queen Victoria Museum, Launceston: $100 \mathrm{pp}$.

Green, R.H., Rainbird, J.L. \& McQuillan, P.B. 1986: Food of the southern boobook Ninox novaeseelandiae. The Tasmanian Naturalist 86: $1-3$.

Grün, R., Moriarty, K. \& Wells, R. 2001: Electron spin resonance dating of the fossil deposits in the Naracoorte Caves, South Australia. Journal of Quaternary Science 16: 49-59.

Guiler, E.R. 1970: Observations on the Tasmanian devil Sarcophilus harrisii (Marsupialia: Dasyuridae). I. Numbers, home range, movements and food in two populations. Australian Journal of Zoology 18: 49-62.

Hall, L.S. 1975: A recent bone deposit at Marble Arch, NSW. In Graham, A.W. (ed.): Proceedings of the Tenth Biennial Conference of the Australian Speleological Federation. Australia Speleological Federation, Sydney: 35-46.

Harris, J.M. 2005: Mammal records from The Tasmanian Naturalist. The Tasmanian Naturalist 127: 20-41.

Harris, J.M. in press: Fossil occurrence of Cercartetus nanus (Marsupialia: Burramyidae) in South Australia. Transactions of the Royal Society of South Australia.

Harris, J.M. \& Goldingay, R.L. 2005a: Distribution, habitat and conservation status of the eastern pygmy-possum (Cercartetus nanus) in Victoria. Australian Mammalogy 27: $185-210$

Harris, J.M. \& Goldingay, R.L. 2005b: The distribution of fossil and sub-fossil records of the eastern pygmy-possum Cercartetus nanus in Victoria. The Victorian Naturalist 122: $160-170$

Harris, J.M., Gynther, I.C., Eyre, T., Goldingay, R.L. \& Mathieson, 
M.T. in press: Distribution, habitat and conservation status of the eastern pigmy-possum Cercartetus nanus in Queensland. Australian Zoologist

Hocking, G. 1979: Mammals. In Gee, H. \& Fenton, J. (Eds): The South West Book: a Tasmanian Wilderness. Australian Conservation Foundation, Hawthorn, Victoria: 121125 .

Hope, J.H. 1973: Mammals of the Bass Strait Islands. Proceedings of the Royal Society of Victoria 85: 163-195.

Hope, G.S. 1978: The Late Pleistocene and Holocene vegetational history of Hunter Island, north-western Tasmania. Australian Journal of Botany 26: 493-514.

Hughes, L. 2003: Climate change and Australia: trends, projections and impacts. Austral Ecology 28: 423-443.

Jones, R. 1984: Hunters and history: a case study from western Tasmania. In Schrire, C. (ed.): Past and present in Hunter Gatherer Studies. Academic Press, Orlando: 27-65.

Jones, R. 1990: From Kakadu to Kutikina: the southern continent at 18000 years ago. In Gamble, C. \& Soffer, O. (eds): The World at 18000 BP. Volume 2. Low Latitudes. Unwin Hyman, Sydney: 264-295.

Jones, R. 1995: Tasmanian archaeology: establishing the sequences. Annual Review of Anthropology 24: 423-446.

Jones, R. \& Allen, J. 1984: Archaeological investigations in the Andrew River Valley, Acheron River Valley and at Precipituous Bluff, southwest Tasmania - February 1984. Australian Archaeology 19: 86-101.

Jones, R., Ranson, D., Allen, J. \& Kiernan, K. 1983. The Australian National University-'Tasmanian National Parks and Wildlife Service expedition to the Franklin River, 1982. Australian Archaeology 16: 57-70.

Jordan, G.J., Carpenter, R.J. \& Hill, R.S. 1991: Late Pleistocene vegetation and climate near Melaleuca Inlet, south-western Tasmania. Australian Journal of Botany 39: 315-333.

Kiernan, K. 1982: A probable Pleistocene occupation site in central-western Tasmania. Australian Archaeology 15: 85-91.

Kiernan, K. 1988: Caves and karst areas of Tasmania - a brief survey. Joumal of the Sydney Speleological Society 32: $107-121$.

Kiernan, K., Jones, R. \& Ranson, D. 1983: New evidence from Fraser Cave for glacial age man in south-west Tasmania. Nature 301: 28-32.

Kirkpatrick, J.B. \& Fowler, M. 1998: Locating likely glacial forest refugia in Tasmania using palynological and ecological information to test alternative climatic models. Biological Conservation 85: 171-182.

Kirkpatrick, J.B., Hutchinson, M.N. \& McQuillan, P.B. 1993: Alpine ecosystems. In Smith, S.J. \& Banks, M.R. (eds): Tasmanian Wilderness - World Heritage Values. Royal Society of Tasmania, Hobart: 73-79.

Kusmer, K.D. 1990: Taphonomy of owl pellet deposition. Journal of Paleontology 64: 629-637.

Long, J., Archer, M., Flannery, T. \& Hand, S. 2002: Prehistoric Mammals of Australia and New Guined: One Hundred Million Years of Evolution. University of New South Wales Press, Sydney: $244 \mathrm{pp}$.

MacPhail, M. 1975: Late Pleistocene environments in Tasmania. Search 6: 295-300.

Mansergh, I.M. \& Broome, L. 1994: The Mountain PygmyPossum of the Australian Alps. University of New South Wales Press, Kensington: $114 \mathrm{pp}$.

Marshall, B. 1986: An experimental evaluation of the criteria used to distinguish owl-deposited bone in archacological cave deposits in Australia. Australian Archaeology 22: 104-121.

Marshall, B. \& Cosgrove, R. 1990: Tasmanian devil (Sacrophilus harrisii) scat bone: signature criteria and archaeological implications. Archaeology in Oceania 25: 102-113.

McNabb, E., Walters, B. \& Bingham, J. 2005: Diet of a Barn Owl Tyto alba at Snake Island, Victoria, including Eastern
Pygmy-possum Cercartetus nanus. The Victorian Naturalist 122: $244-246$.

McNiven, I., Marshall, B., Allen, J., Stern, N. \& Cosgrove, R. 1993: The southern forests archaeological project: an overview. In Smith, M.A., Spriggs, M. \& Fankhauser, B. (eds): Sahul in review: Pleistocene archaeology in Australia, New Guinea and island Melanesia. Department of Prehistory, Research School of Pacific Studies, Australian National University, Canberra: 213-224.

McWilliams, R., Allen, J., Cosgrove, R. \& Holdaway, S. 1999: Report of the southern forests archaeological project. Volume 3: Archaeological Database. Archaeology Publications, Department of Archacology, La Trobe University, Melbourne.

Menkhorst, P.W. (ed) 1995: Mammals of Victoria:Ddistribution, Ecology and Conservation. Oxford University Press, Melbourne: 359 pp.

Menkhorst, P. \& Knight, F. 2001: A field guide to the mammals of Australia. Oxford University Press, Melbourne: $269 \mathrm{pp}$.

Middleton, G.J. 1979: Wilderness Caves: a preliminary survey of the Gordon-Franklin River System. Occasional Paper No. 11. Centre for Environmental Studies, University of Tasmania, Hobart: $110 \mathrm{pp}$.

Mooney, N. 1992: Diet of the Masked Owl in Tasmania. Tasmanian Bird Report 21: 35-55.

Mooney, N. 1993: Diet of the Masked Owl in Tasmania: past and present. In Olsen, P. (ed.): Australian Raptor Studies. Australian Raptor Association and Royal Australiasian Ornithogists Union, Melbourne: 160-174.

Muirhead, J. 1990: Report on the Fossil-Subfossil Fauna from Ida Bay Caves. Unpublished report to Department of Parks, Wildlife and Heritage, Tasmania: 34pp.

Mumbray, T. 1992: A note on the analysis of a series of dasyurid scats. The Tasmanian Naturalist 109: 1-4.

Munks S.A, Mooney N., Pemberton D. \& Gales R. 2004: An update on the distribution and status of possums and gliders in Tasmania, including off-shore islands. In Goldingay, R.L. \& Jackson, S.M. (eds): The Biology of Australian Possums and Gliders. Surrey Beatty and Sons, Chipping Norton: 111-29.

Murray, P.F. 1979: Life in the Late Pleistocene. In Gee, H. \& Fenton, J. (eds): The South West Book: a Tasmanian Wilderness. Australian Conservation Foundation, Hawthorn, Victoria: 127-129.

Murray, P.F. \& Goede, A. 1977: Pleistocene vertebrate temains from a cave near Montagu, N.W. Tasmania. Records of the Queen Victoria Museum 60: 1-30.

Murray, P.F., Goede, A. \& Bada, J.L. 1980: Pleistocene human occupation at Beginner's Luck Cave, Florentine Valley, Tasmania. Archaeology and Physical Anthropology in Oceania 15: $142-152$.

Northwood, C. 1990: A taphonomic analysis of Sacrophilus harrisiz in Australian archaeological sites. Unpublished Hons thesis, La Trobe University, Melbourne.

Pocock, C. 1992: A report on the excavation of Maneena Langatick Tattana Emita (TAS 2867): a report to the Hydro-Electric Commission of Tasmania. Centre for Prehistory, University of Western Australia and Hydro-Electric Commission of Tasmania: $90 \mathrm{pp}$.

Pocock, C. 1993: Excavation of limestone caves in the Nelson River Valley, central western Tasmania. In Smith, M.A., Spriggs, M. \& Fankhauser, B. (eds): Sahul in review: Pleistocene archaeology in Australia, New Guined and island Melanesia. Department of Prehistory, Research School of Pacific Studies, Australian National University, Canberra: 240-246.

Prescott, J.R. \& Robertson, G.B. 1997: Sediment dating by lumninscence: a review. Radiation Measurements 27: 893-922.

Reed, E.H. \& Bourne, S.J. 2000: Pleistocene fossil vertebrate sites of the south east region of South Australia. Transactions of 
the Royal Society of South Australia 124: 61-90.

Reid, R.B., Hill, R.S., Brown, M.J. \& Hovenden, M.J. (eds) 1999: Vegetation of Tasmania. Australian Biological Resources Study, Canberra: 456 pp.

Rich, T.H., Archer, M., Plane, M.D., Flannery, T.F., Pledge, N.S., Hand, S.J. \& Rich, P.V. 1982: Australian tertiary mammals. In Rich, P.V. \& Thompson, E.M. (eds): The Fossil Vertebrate Record of Australiasia. Monash University Offset Printing Unit, Clayton: 525-572.

Ride, W.D.L. 1960: The fossil mammalian fauna of the Burramys parvus breccia from the Wombeyan Caves, New South Wales. Journal of the Royal Society of Western Australia 43: 74-80.

Rounsevell, D. E., Taylox, R. J. \& Hocking, G. J. 1991: Distribution records of native terrestrial mammals in Tasmania. Wildlife Research 18: 699-717.

Sim, R. 1998: The archaeology of isolation? Prehistoric occupation in the Furneaux Group of Islands, Bass Strait, Tasmania. Unpublished PhD thesis. Australian National University, Canberra.

Smith, M.A. \& Sharp, N.D. 1993: Pleistocene sites in Australia, New Guinea and Island Melanesia: geographic and temporal structure of the archaeological record. In Smith, M.A., Spriggs, M. \& Fankhauser, B. (eds): Sahul in review: Pleistocene Archaeology in Australia, New Guined and Island Melanesia. Department of Prehistory, Research School of Pacific Studies, Australian National University, Canberra: 37-59.

Stern, N. \& Marshall, B. 1993: Excavations at Mackintosh 90/1 in western Tasmania: a discussion of stratigraphy, chronology and site formation. Archaeology in Oceania 28: 8-17.

Strahan, R. (ed.) 1995. The Mammals of Australia. Reed books, Chatswood: $756 \mathrm{pp}$.
Tedford, R.H. \& Kemp, N.R. 1998: Oligocene marsupials of the Geilston Bay Local Fauna, Tasmania. American Museum Novitates 3244: 1-22.

Tedford, R.H., Banks, M.R., Kemp, N.R., McDougall, I. \& Sutherland, F.L. 1975: Recognition of the oldest known fossil marsupials from Australia. Nature 255: 141-142.

Tulloch, A. 2004: The importance of food and shelter for habitat use and conservation of the burramyids in Australia. In Goldingay, R.L. \& Jackson, S.M. (eds): The Biology of Australian Possums and Gliders. Surrey Beatty and Sons, Chipping Norton: 268-284.

Vanderwal, R.L. 1979: Pre-history and the archaeology of Louisa Bay. In Gee, H. \& Fenton, J. (eds): The South West Book: a Tasmanian Wilderness. Australian Conservation Foundation, Hawthorn, Victoria: 17-21.

van Weenen, J. \& Harris, J.M. 2006. The eastern pygmy-possum in South Australia. The South Australian Naturalist 80: 4-11.

Wakefield, N.A. 1960: Recent mammal bones from the Buchan district - 1. Victorian Naturalist 77: 164-178.

Wakefield, N.A. 1972: Palaeoecology of fossil mammal assemblages from some Australian caves. Proceedings of the Royal Society of Victoria 85: 1-26.

Wall, L.E. 1985: Little pigmy possum Cercartetus lepidus. The Tasmanian Naturalist 80: 10-11.

Wallis, R.L., Drew, R.N., Duke, G.F. \& Forbes, S.J. 1977: The prey of a native cat in south-west Tasmania. The Tasmanian Naturalist 48: 4.

Ward, S.J. 1992: Life history of the little pygmy-possum, Cercartetus lepidus (Marsupialia: Burramyidae), in the Big Desert, Victoria. Australian Journal of Zoology 40: 43-55.

Watts, D. 1987: Tasmanian Mammals: a Field Guide. Peregrine Press, Tasmania: 46-47.

(accepted 3 July 2006) 